\title{
The patter of tiny feet
}

\author{
A blast from the past.
}

\section{Guy Riddihough}

Gilliam Wilbert read the news article with something akin to shocked disbelief. "Cockroach Extinct: household vermin bites the dust. Blattella germanica, the last remaining extant species of cockroach, has finally gone the way of the rat..."

Gilliam dug out the pile of old Schmidt boxes his grandfather, long dead, had made as part of a collection for the now defunct local museum. Gilliam had smuggled them into his cramped studio apartment one evening when the surveillance cameras had gone on the blink. Every species of cockroach: it had been the old man's speciality - more than that, the love of his life.

"See here, Gilly. A death's head cockroach. What a beauty, eh?" The young Gilliam had stared in awe. "And this one: here, put your hand out." Gilliam loved his grandfather deeply, still, he had trembled a little as the old man plopped something concealed and wriggling into his hand. "A giant burrowing cockroach, biggest in the world." Gill had looked with fascination at the plump brown insect that filled his child's hand. It had squirmed and wriggled lazily, too fat to run away.

Gilliam hunted through the Schmidt boxes and found the selfsame species, labelled Macropanesthia rhinoceros. $\mathrm{He}$ wondered if this might be the very insect grandpapa had let him handle all those years ago. How the old man had rambled on, Gilliam sitting on his knee: "These beauties have been with us for a hundred million years, since the peak of the dinosaurs, Gilly. Tough as nails, live without food for a month, and then they can scrape a living off no more than the glue on the back of a postage stamp."

At university Gilliam had taken a course in entomology, but it was already a dead science by then: almost all living insect specimens existed in a dwindling number of zoos. He had been forced to change to biochemical nutrient engineering. With the human population then at several tens of billions and counting, there was no room for anything not linked to the streamlined and efficient production of human biomass. Most fauna and flora were functionally extinct with space-efficient genome banks taking the place of the last protected habitats.

Slowly, through the years, he came to look upon the little scurrying creatures as tiny arthropod revolutionaries, a secret last stand against an increasingly sterile world. And now even the cockroach had succumbed to the ever-expanding plague of humankind.

Gilliam riffled through the little kit as he took the tram back to the trans-Pennine dormitory megalopolis. Several small plastic tubes; the miniature disposable autocycler block; the little packet of freeze-dried host eggs with the word 'arthro' scribbled in marker pen on it. A legacy from one of his entomology practical courses: Species Resurrection 101.

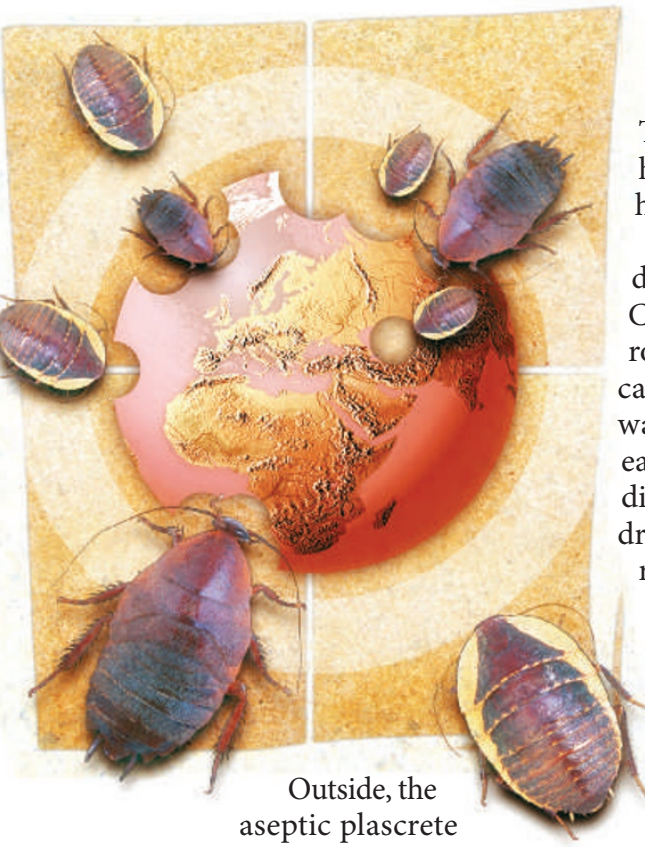

and they, too, darkened to a soft golden brown.

Gilliam had sometimes dreamed of waking up as a cockroach, lying on his back, his insectile legs waving in the air. He'd roll onto the floor and scuttle across to a dark crack in the wall, twisting and squirming his way through. Safe in the darkness he'd be gripped by a sense of utter, total freedom.

"You little creatures spanned the globe," he whispered to them, "east to west, north to south, everywhere that humans went. And now..." He was cut short by a pound-

ing at the door. Startled, he knocked the insectarium over, accidentally spilling its contents.

The biocrimes interrogator clasped his hands together on the desk in front of him.

"Gilliam, I'm on your side, but this does not look good, any way you spin it. Cockroaches, for crying out loud. Cockroaches live on filth, Gilliam, and they carry all kinds of nasty diseases. They walk all over our food and we end up eating our own filth and catching those diseases. Did you know that cockroach droppings cause potentially fatal allergic reactions, Gilliam?"

They took him to a holding cell.

"It's worse than I thought, Gilliam." The biocrimes interrogator wrinkled his nose at the smell and appeared to inspect a fingernail with great interest. "Those 'roaches you released, they're resistant to goddam nearly urbanscape slid silently by, tidy and neat. And in the far corner of the carriage, unseen by Gilliam, a minute camera swivelled and focused.

Back in his cramped apartment Gilliam opened one of the Schmidt boxes and selected a sample at random; Periplaneta americana. His heart thudded in his chest - all biotech activity was strictly regulated - but his hesitation lasted no more than an instant. He crushed the insect's mummified body into one of the tubes and slowly worked his way through the handwritten instructions he had penned at university, years before.

Over the following weeks the tiny eggs swelled and became taut, glistening in the dim light of the insectarium hidden away in his closet. The pale white nymphs hatched and grew and darkened, prospering under Gilliam's loving hand. The nymphs moulted into pale white adults, everything. What the hell were you doing? The prosecution is pushing for the big one."

"The what?" Gillian asked, the words whistling through broken teeth.

"Bioterrorism. You synthesized a listed biohazardous species.”

Gilliam looked down at his bruised and swollen hands, "I just wanted to bring them back to life."

They threw the book at Gilliam, and he spent many years in a cell only slightly smaller than his apartment. Indeed, he might have spent the rest of his days there had it not been for a plague that swept the planet clean of most of the rest of the human race. A plague - it was rumoured - borne on the feet of cockroaches.

The author is presently locked in a deadly cosmic battle with Nature - as he is an editor at Science, but has declared a truce for the length of this story. 